\title{
Different effect of serotonin on intracellular calcium ion dynamics in the smooth muscle cells between rat posterior ciliary artery and vorticose vein
}

\author{
Masatoshi Oкubo ${ }^{1,2}$, Yoh-ichi Satoh ${ }^{1,3}$, Masato Hirakawa ${ }^{1}$, Kana Sasaki ${ }^{1}$, Kazuki Masu', Gabriel J. \\ Mchonde $^{1}$, Chika Ikeda-Kurosawa ${ }^{1,2}$, Daijiro Kurosaka ${ }^{2}$, and Tomoyuki Saino ${ }^{1}$ \\ ${ }^{1}$ Department of Anatomy (Cell Biology), ${ }^{3}$ Department of Medical Education, Iwate Medical University, Shiwa-gun, Iwate, Japan and \\ ${ }^{2}$ Department of Ophthalmology, School of Medicine, Iwate Medical University, Morioka, Iwate, Japan
}

(Received 25 January 2016; and accepted 9 February 2016)

\begin{abstract}
5-hydroxytriptamine (5-HT: serotonin) is an important transmitter that causes vessel constriction, although few studies have examined the effect of 5-HT on venous smooth muscles. The intracellular $\mathrm{Ca}^{2+}$ concentration $\left(\left[\mathrm{Ca}^{2+}\right]_{i}\right)$ plays an essential role in stimulus-response coupling in numerous tissue/cells including vascular smooth muscle cells. The present study was performed to examine whether differences between arteries and veins in the response to 5-HT can be detected under confocal microscope with respect to $\left[\mathrm{Ca}^{2+}\right]_{i}$ dynamics. In posterior ciliary arteries of rats, 5-HT induced a $\left[\mathrm{Ca}^{2+}\right]_{\mathrm{i}}$ increase. The 5-HT-induced responses were caused by both $\mathrm{Ca}^{2+}$ influx and mobilization. Agonist and antagonist experiments revealed that arterial smooth muscles possess $5-\mathrm{HT}_{1 \mathrm{a}, 1 \mathrm{~b}, 2}$ (Gprotein-coupled type) and 5- $\mathrm{HT}_{3}$ (ion channel type) receptors, and that $5-\mathrm{HT}_{2}$ in particular plays a major role in these responses. For vorticose veins, the 5-HT-induced responses were also caused by both $\mathrm{Ca}^{2+}$ influx and mobilization. However, the cAMP dependent pathway $\left(5-\mathrm{HT}_{4-7}\right)$ was found to be significant in vasocontraction with respect to 5 - $\mathrm{HT}$ in these vessels. Thus, $\mathrm{Ca}^{2+}$ mobilization was induced by $5-\mathrm{HT}_{2}$ and $5-\mathrm{HT}_{4-7}$ in a vessel-dependent manner, whereas $\mathrm{Ca}^{2+}$ influx universally was induced by $5-\mathrm{HT}_{3}$. These results indicate that the posterior ciliary arteries and vorticose veins in the same tissue might differ greatly in their responses to stimulus.
\end{abstract}

Retinal vein occlusion is the second most common retinal vascular disorder after diabetic retinopathy and is considered to be an important cause of visual impairment $(9,54)$. Ischemic disorders of the optic nerve constitute an important cause of visual loss $(7$, 30). For example, ischemic optic neuropathy, an acute disorder of the optic nerve, is now known to be a common yet serious vision-threatening disease in middle-aged and elderly populations $(13,72)$. Similarly, evidence is mounting that vascular insufficiency in the intraorbital portion of the optic nerve

Address correspondence to: Tomoyuki Saino, MD, Ph.D. Department of Anatomy (Cell Biology), Iwate Medical University, 2-1-1 Nishitokuta, Yahaba-cho, Shiwa-gun, Iwate 028-3694, Japan

Tel: +81-19-651-5111, Fax: +81-19-908-8006

E-mail: tsaino@iwate-med.ac.jp might play an important role in amorose glaucomatous optic neuropathy and papilloedema $(65,83)$.

The main vascular sources of the intraorbital portion of the optic nerve consist of the branches of the posterior ciliary artery and the central retinal artery $(29,36,50,79)$. The choroid blood vessels of the eye provide $80-95 \%$ of the blood to the ocular structures including the outer retina and ciliary processes (6). The central retinal artery supplies the optic nerve and the inner retina, while the posterior ciliary artery pierces the sclera to enter the choroidal coat of the eye. The central retinal artery ends without significant anastomoses (32). The choroidal vessels are innervated by sympathetic and parasympathetic nerves; the parasympathetic innervation of the choroid derives from the ipsilateral pterygopalatine ganglion (59). Parasympathetic nerve stimulation produces nitric oxide-mediated vasodilation, which 
appears to be selective for vessels in the anterior choroid (67). Sympathetic nerves from the superior cervical ganglion project to the choroid and, when stimulated, elicit marked vasoconstriction throughout the choroid $(39,67)$.

The retinal vasculature shares many anatomical and physiological features with the cerebral and coronary vasculature, which are exposed to similar intrinsic and environmental influences $(17,53)$. Retinal vessel caliber sizes convey different information about systemic diseases, with arteriolar narrowing being associated with elevated blood pressure (10, $40,81)$. Notably, several general diseases cause blindness in patients following simultaneous combined retinal artery and vein occlusion. Central retinal artery occlusions result from localized arteriosclerotic changes, an embolic event, which typically presents as a sudden, severe, and painless visual loss (31, 52). With regard to morphological studies of these disorders, corrosion casts of the retinal vasculature of small animals such as rats and mice can be used to demonstrate the effects of systemic diseases on the retinal vasculature because good models of hereditary or spontaneous systemic diseases are available. Several studies on corrosion cast vasculature of the retina have been reported $(4,20,21,51)$. It is well known that the shape and distributions of smooth muscle cells differ between artery/arterioles and vein/venules. The morphological differences of smooth muscle cells can indicate their different roles in vivo. However, the data available on the physiological characteristics of vein/venule smooth muscle cells is extremely limited.

5-hydroxytriptamine (5-HT: serotonin) is a neurotransmitter that is involved in a wide variety of physiological functions via its interaction with multiple receptor subtypes, mainly in the central and peripheral nervous systems and in the gastrointestinal tract $(2,8,12,55)$. In addition, 5-HT is a wellknown potent vasoconstrictor agent in several arteries $(77,78,80)$. A role for 5 -HT in the control of brain perfusion has been widely considered $(41,85,86)$. More specifically, 5-HT has been implicated in cerebrovascular dysfunctions such as vasospasm and migraine $(18,19)$. For example, the level of $5-\mathrm{HT}$ in cerebrospinal fluid was shown to be elevated immediately after subarachnoid hemorrhage and demonstrated to be involved in fatal vasospasmus (60). Our present understanding of the role of 5-HT in cardiovascular regulation is based on the knowledge that there are seven main types of 5-HT receptors $\left(5-\mathrm{HT}_{1}\right.$ to $\left.5-\mathrm{HT}_{7}\right)(34,35,56)$. With the exception of the $5-\mathrm{HT}_{3}$ receptor, which is a ligand-gated ion chan- nel, each of the identified 5-HT receptors represents a seven-transmembrane domain, G-protein-coupled receptor $(25,34)$. The $5-\mathrm{HT}_{1}$ and $5-\mathrm{HT}_{4-7}$ receptor family members couple with adenylyl cyclase, whereas binding of 5-HT to the Gq-coupled 5- $\mathrm{HT}_{2}$ receptor activates phospholipase $\mathrm{C}$, resulting in the release of inositol triphosphate and an elevation of cytosolic calcium. Furthermore, the 5- $\mathrm{HT}_{2}$ family receptors are important for the mediation of a number of physiological functions including vascular and nonvascular smooth muscle contraction (58).

The aim of this study was to clarify the $\mathrm{Ca}^{2+}$ signaling mechanism of 5-HT in the smooth muscle cells of the posterior ciliary artery and vorticose vein in the rat. Although it is very important to understand the pathophysiology underlying disorders such as hypertension and cerebrovascular diseases, only a few studies of intracellular $\mathrm{Ca}^{2+}$ concentration $\left(\left[\mathrm{Ca}^{2+}\right]_{\mathrm{i}}\right)$ changes in intact veins are currently available. Previously, we have demonstrated that adenosine triphosphate (ATP) participates in a variety of actions in the arterioles of different tissues (62), and subsequently investigated the $\left[\mathrm{Ca}^{2+}\right]_{\mathrm{i}}$ dynamics in individual cells in intact arteriole specimens using real-time confocal laser scanning microscopy, which has excellent time and spatial resolution $(42,44,46,61-$ 63). In particular, we showed that the reaction of arteriole smooth muscle cells to 5-HT differs between testis and brain arterioles, which emphasizes the possibility of a characteristic regional cerebral blood circulation (42). Compared to the previously utilized technologies, the present study reports the investigation of alterations in the $\left[\mathrm{Ca}^{2+}\right]_{i}$ of smooth muscle cells in the posterior ciliary arteries and vorticose veins in response to 5-HT and selected modifying reagents.

\section{MATERIALS AND METHODS}

Preparation of the ciliary arteries and vorticose veins. Experiments were conducted according to the guidelines of the ethics committee for animal treatment of Iwate Medical University. Adult male rats (Wistar, 8-12 weeks old, body weight 250-400 g) were euthanized by carbon dioxide gas. They were then perfused via the left cardiac ventricle with Ringer's solution $(147 \mathrm{mM} \mathrm{NaCl}, 4 \mathrm{mM} \mathrm{KCl}$, and $\left.2.25 \mathrm{mM} \mathrm{CaCl}_{2}\right)$ at $25^{\circ} \mathrm{C}$ at a hydrostatic pressure of approximately $1 \mathrm{~m} \mathrm{H}_{2} \mathrm{O}$. After wash-out of the blood cells from the vessels, the eye balls were removed and placed in Hepes-buffered Ringer's solution (HR). The HR solution contained $118 \mathrm{mM} \mathrm{NaCl}, 4.7 \mathrm{mM}$ $\mathrm{KCl}, 1.25 \mathrm{mM} \mathrm{CaCl}_{2}, 1.13 \mathrm{mM} \mathrm{MgCl}_{2}, 1 \mathrm{mM}$ 
$\mathrm{NaH}_{2} \mathrm{PO}_{4}, 5.5 \mathrm{mM}$ D-glucose, MEM amino acids solution (Gibco, Grand Island, NY, USA), 0.2\% bovine serum albumin (Sigma, St. Louis, MO, USA), and $10 \mathrm{mM}$ Hepes; $\mathrm{pH} 7.4$, adjusted with $\mathrm{NaOH}$. The posterior ciliary arteries and vorticose veins were isolated from the eyes and were digested with collagenase $(100 \mathrm{U} / \mathrm{mL}$; Elastin Products, Owensville, MO, USA) in HR solution for $2 \mathrm{~h}$ at $37^{\circ} \mathrm{C}$. The connective tissues were then carefully removed. $\mathrm{Ca}^{2+}$ deficient solutions were prepared by replacing $\mathrm{CaCl}_{2}$ with EGTA (1.0 mM; Sigma).

Intracellular $\mathrm{Ca}^{2+}$ imaging. To measure $\left[\mathrm{Ca}^{2+}\right]_{\text {in }}$, the arteries and veins were placed on a glass cover slip, set in a perfusion chamber, and incubated with $10 \mu \mathrm{M}$ Indo-1/AM (Indo-1/AM; Dojindo, Kumamoto, Japan) in the HR solution for $2 \mathrm{~h}$ at $37^{\circ} \mathrm{C}$. Indo-1 (excited by ultraviolet light) is a ratiometric dye that is used in the quantitative determination of $\left[\mathrm{Ca}^{2+}\right]_{\mathrm{i}}$. The emission maximum of Indo-1 shifts from $475 \mathrm{~nm}$ in $\mathrm{Ca}^{2+}$-free medium to $400 \mathrm{~nm}$ when the dye solution is saturated with $\mathrm{Ca}^{2+}$. The ratio of the intensity of the emissions shorter than $440 \mathrm{~nm}$ to that of those longer than $440 \mathrm{~nm}$ can be used to estimate the $\left[\mathrm{Ca}^{2+}\right]_{\mathrm{i}}$; a higher ratio indicates a higher $\left[\mathrm{Ca}^{2+}\right]_{\mathrm{i}}$. Artifacts, which include photobleaching and dye leakage, can be eliminated by use of this ratiometry.

A real-time confocal microscope ( $\mathrm{RCM} / \mathrm{Ab}$; a modified version of a Nikon model RCM-8000, Tokyo) was used to measure the $\left[\mathrm{Ca}^{2+}\right]_{\mathrm{i}}$ changes. Cells that had been loaded with Indo-1 were exposed to an ultraviolet-beam $(351 \mathrm{~nm})$. An argon-ion laser equipped with an inverted microscope (TE-300, Nikon) was used wherein the fluorescence emission was passed through a water-immersion objective lens (Nikon C Apo 40×, N.A. 1.15) to a pinhole diaphragm. The acquisition time per image frame was $1 / 30 \mathrm{~s}$ using this system. Images were immediately stored on high-speed hard disks. The digital images from the laser scanning microscopic imaging were composed of $512 \times 480$ pixels with a density resolution of 8 bits/pixel. The fluorescence intensity was displayed in pseudocolor with 256 colors, with red representing high $\left[\mathrm{Ca}^{2+}\right]_{\mathrm{i}}$ and purple and blue representing low $\left[\mathrm{Ca}^{2+}\right]_{\mathrm{i}}$. We measured $\left[\mathrm{Ca}^{2+}\right]_{\mathrm{i}}$ in restricted areas (spot size of approximately $3 \mu \mathrm{m}^{2}$ ) by ratiometry.

Stimulation by 5-HT and selected reagents. The $\left[\mathrm{Ca}^{2+}\right]_{\mathrm{i}}$ dynamics of the arteries and veins were examined in a perfusion chamber as rapidly as possible after the dye-loading. After perfusion with the standard HR for a few minutes at room temperature, intact arteries and veins were selected and examined under the microscope. Specimens were continuously perfused with HR containing the following agonists and/or antagonists: 5-HT (Nacalai Tesque, $10 \mu \mathrm{M}$ ); $\mathrm{GdCl}_{3}$ (a nonspecific cation channel blocker; Wako, Japan, $100 \mu \mathrm{M}$ ); diltiazem (a L-type $\mathrm{Ca}^{2+}$ channel blocker, $40 \mu \mathrm{M}$ ); thapsigargin (a sarco-endoplasmic reticulum $\mathrm{Ca}^{2+}$-ATPase inhibitor, $2 \mu \mathrm{M}$ ); U73122 (a phospholipase $\mathrm{C}$ inhibitor, $5 \mu \mathrm{M}$ ); SQ22536 (an adenylyl cyclase inhibitor, $100 \mu \mathrm{M}$ ); ketanserin (a 5-HT antagonist, $1 \mu \mathrm{M}$ ); 8-Hydroxy-DPAT (a 5-HT 1 agonist, $50 \mu \mathrm{M}$ ), all from Sigma; CP93129 (a 5-HT agonist, $10 \mu \mathrm{M}$ ); ML 9 (a selective myosin light chain kinase inhibitor, $10 \mu \mathrm{M}$ ); $\mathrm{PKI}_{(14-22)}$ (a cell-permiable protein kinase A (PKA) inhibitor, $2 \mu \mathrm{M}$ ), all from TOCRIS (Minneapolis, MN, USA), $\alpha$-methylserotonin maleate (a 5- $\mathrm{HT}_{2}$ agonist, $100 \mu \mathrm{M}$ ); 2-methylserotonin maleate (a 5- $\mathrm{HT}_{3}$ agonist, $100 \mu \mathrm{M}$ ); and $\mathrm{H}-89$ (a PKA antagonist, $20 \mu \mathrm{M}$ ), all from Enzo Life Sciences (Farmingdale, NY, USA).

Ultrastructure analysis. We utilized light microscopy to examine the vasculatory ultrastructures of the arteries and veins within a subject eyeball. The tissue was cut into small pieces (approximately $5 \mathrm{~mm} \times$ $5 \mathrm{~mm}$ ) and fixed in $0.125 \%$ glutaraldehyde and $4 \%$ paraformaldehyde in phosphate-buffered saline (PBS; $100 \mathrm{mM}$ ) for approximately $4 \mathrm{~h}$ at room temperature. The specimens were then postfixed in 1\% osmium tetroxide (Merck, Darmstadt, Germany) in PBS for $1.5 \mathrm{~h}$ at $4^{\circ} \mathrm{C}$, dehydrated through an ethanol series, and embedded in Epon 812 (TAAB, Berkshire, UK). Semi-thin sections $(\sim 1 \mu \mathrm{m}$ thick) were were consecutively cut using an ultramicrotome (2088 Ultrotome; LKB, Bromma, Sweden) and stained with toluidine blue. The sections were examined by light microscopy.

\section{RESULTS}

Structures of the posterior ciliary artery and vorticose veins

Light microscopy revealed that the specimens prepared for the intracellular calcium imaging maintained the typical structural integrity of posterior ciliary arteries and veins (Fig. 1). The posterior ciliary arteries were surrounded by smooth muscle cells in a circular fashion, and the ciliary arteries contained considerably more smooth muscle within their walls than did the vorticose veins.

The structural integrity of the arterioles was maintained in the prepared specimens. Images of a posterior ciliary artery and a vorticose vein obtained 


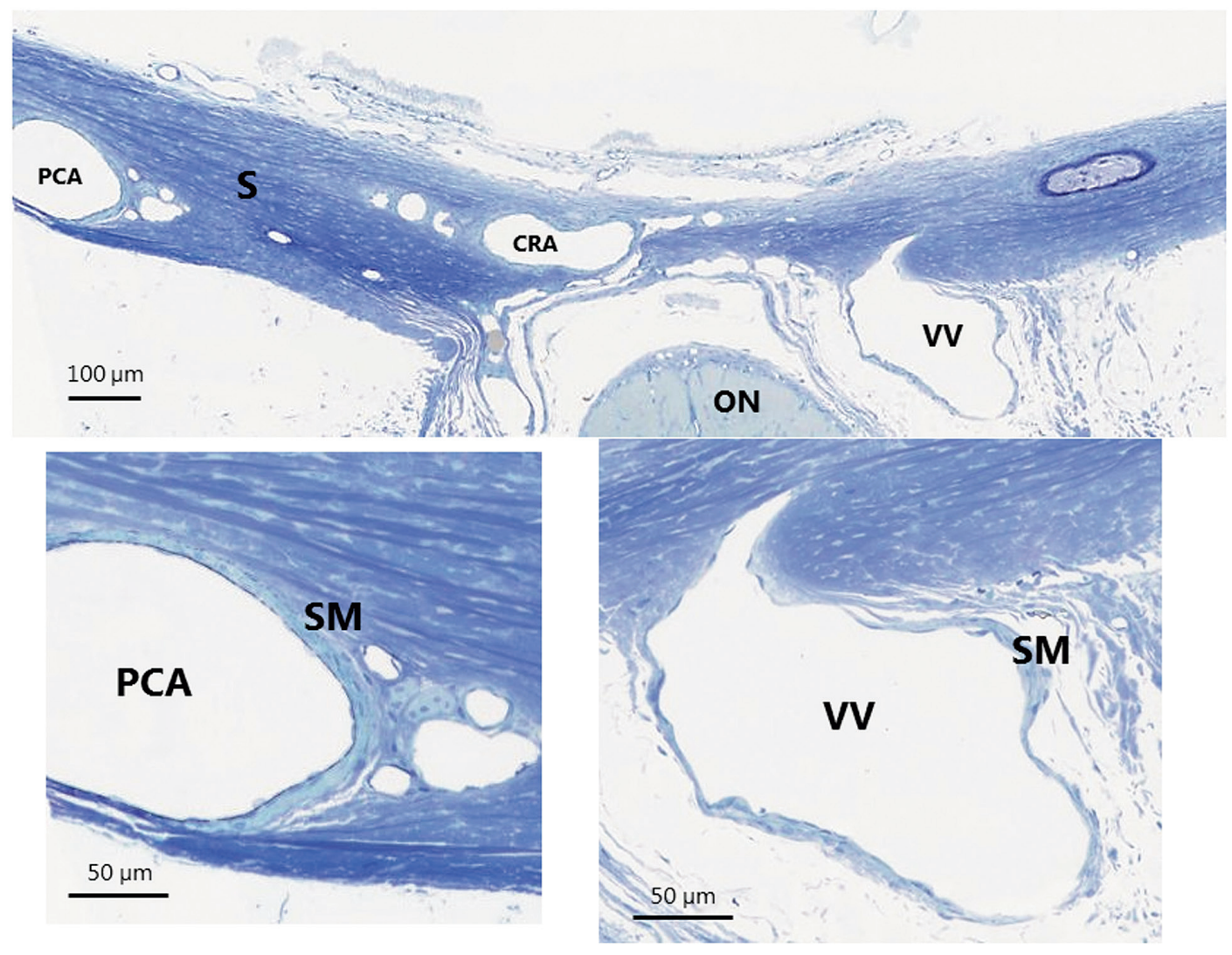

Fig. 1 Light micrographs of a posterior ciliary artery and vorticose vein around the rat optic nerve head. ON: optic nerve, S: sclera, CRA: central retinal artery, PCA: posterior ciliary artery, VV: vorticose vein, SM: smooth muscles.

using real-time confocal laser scanning microscopy are shown in Fig. 2. The arteries were surrounded by spindle-shaped smooth muscle cells in a circular fashion (Fig. 2a). In scanning electron microscopy studies, we have previously shown that the testicular and cerebral arterioles exhibited the same external appearance as that described above (62). However, in this study we noted considerable differences between the arterial and venous structures; wherein the vorticose veins were surrounded by smooth muscle cells in the shape of cobblestones (Fig. 2b).

\section{5-HT-induced $\left[\mathrm{Ca}^{2+}\right]_{i}$ increase in posterior ciliary arteries}

Arterial specimens were perfused with normal HR for $5 \mathrm{~min}$ before stimulation by the selected reagents. Under resting conditions, no spontaneous $\left[\mathrm{Ca}^{2+}\right]$ changes were observed. Injured cells in the arterioles, which showed high $\left[\mathrm{Ca}^{2+}\right]_{i}$ at resting conditions, were excluded from the subsequent analyses. No structural difference was detected between the controls and the specimens with respect to Indo-1/ AM loading.
5-HT $(10 \mu \mathrm{M})$ induced an increase in $\left[\mathrm{Ca}^{2+}\right]_{\mathrm{i}}$ in the smooth muscle cells of posterior ciliary arteries (external diameters $<50 \mu \mathrm{m}$ ) (Fig. 3a). The increase was rapid and oscillatory fluctuation or persistent increases were sometimes observed. Contraction of the arterioles was evidenced. In the absence of extracellular $\mathrm{Ca}^{2+}$, the increase in $\left[\mathrm{Ca}^{2+}\right]_{\mathrm{i}}$ was not completely inhibited $(n=10)$ (Fig. $3 b)$. The effect of $\mathrm{Gd}^{3+}(100 \mu \mathrm{M})$, a nonspecific cation-channel blocker, was the same as that observed in the absence of $\mathrm{Ca}^{2+}(n=8)$ (Fig. 3c). Furthermore, no complete inhibition of 5-HT-induced $\left[\mathrm{Ca}^{2+}\right]_{\mathrm{i}}$ increases was observed following treatment with diltiazem $(50 \mu \mathrm{M})$, an L-type $\mathrm{Ca}^{2+}$-channel blocker $(n=8)$ (data not shown). In general, metabotropic receptors are Gprotein-linked, and $G$ protein stimulation activates phospholipase $\mathrm{C}$, which cleaves membrane-bound phosphatidyl-inositol-biphosphate to generate inositol-triphosphate $\left(\mathrm{IP}_{3}\right)$ and diacylglycerol. This $\mathrm{IP}_{3}$ subsequently causes $\mathrm{Ca}^{2+}$ mobilization from the internal stores (3). To determine if this mechanism of $\mathrm{Ca}^{2+}$ mobilization was involved in the 5-HT-induced $\left[\mathrm{Ca}^{2+}\right]_{\mathrm{i}}$ increase, the effects of thapsigargin and 

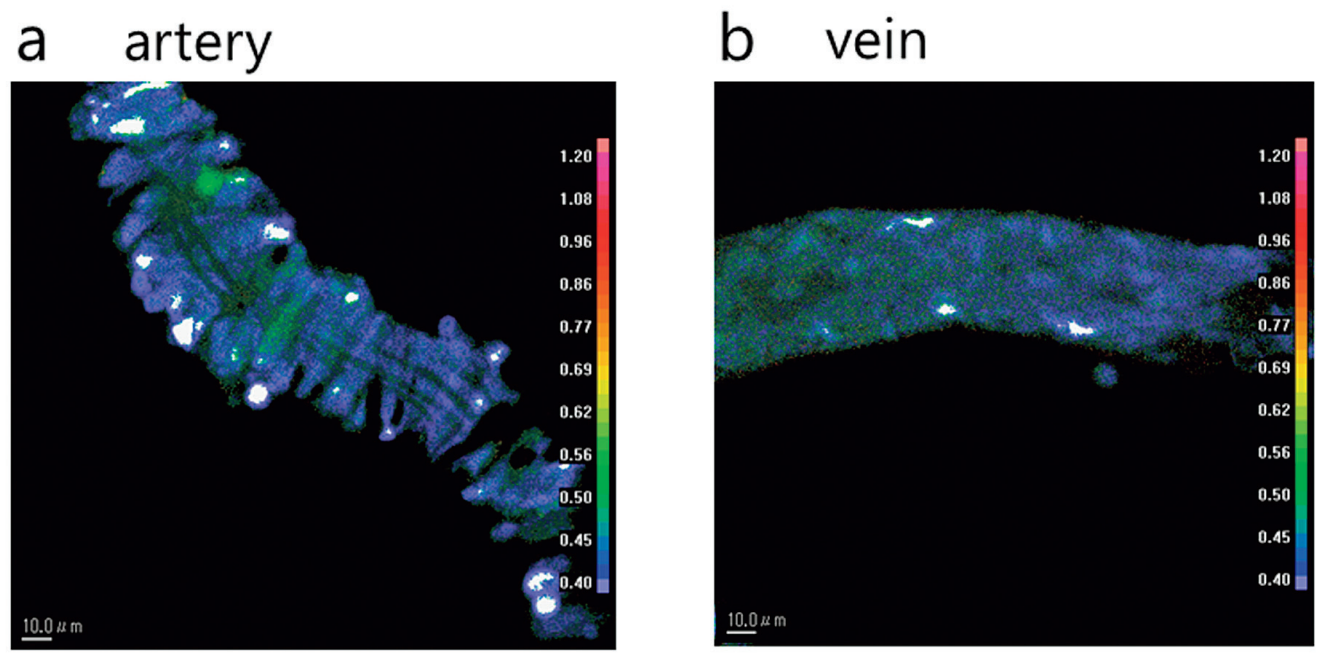

Fig. 2 Comparison between real-time confocal laser scanning micrographs of rat posterior ciliary arterial and vorticose venous smooth muscle cells. (a): Real-time confocal laser scanning micrograph of a rat posterior ciliary artery. The artery is surrounded by spindle-shaped smooth muscle cells in a circular fashion. (b): Real-time confocal laser scanning micrograph of a rat vorticose vein. The vein is surrounded by smooth muscle cells in the shape of cobble stones. Specimens were perfused with normal HR for $5 \mathrm{~min}$ before stimulation with the selected reagents. Color scale bar: fluorescence ratios representing $\left[\mathrm{Ca}^{2+}\right]_{\mathrm{i}}$.

\section{a}

Ratio
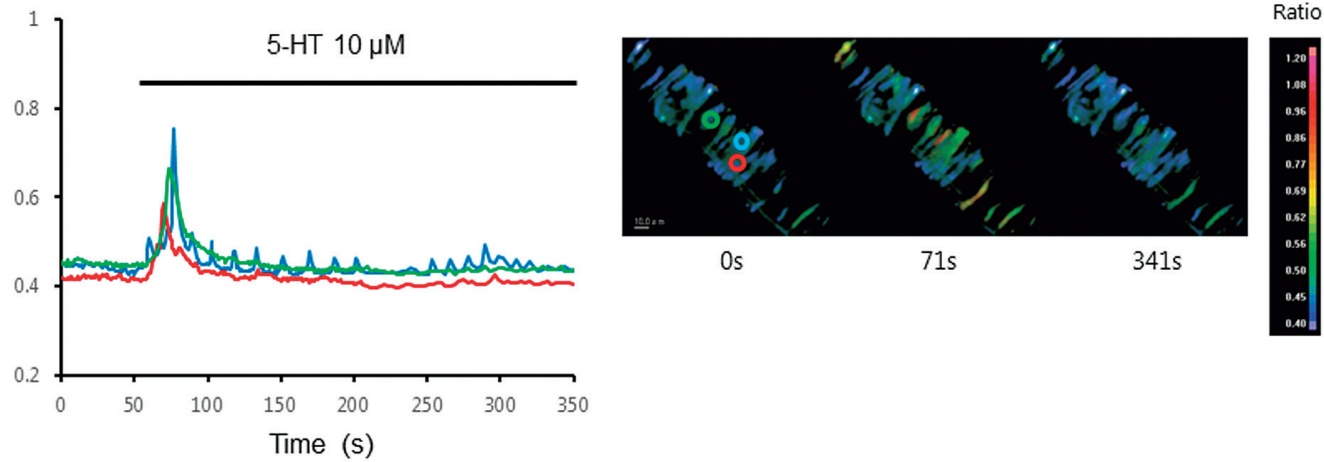

b

Time (s)
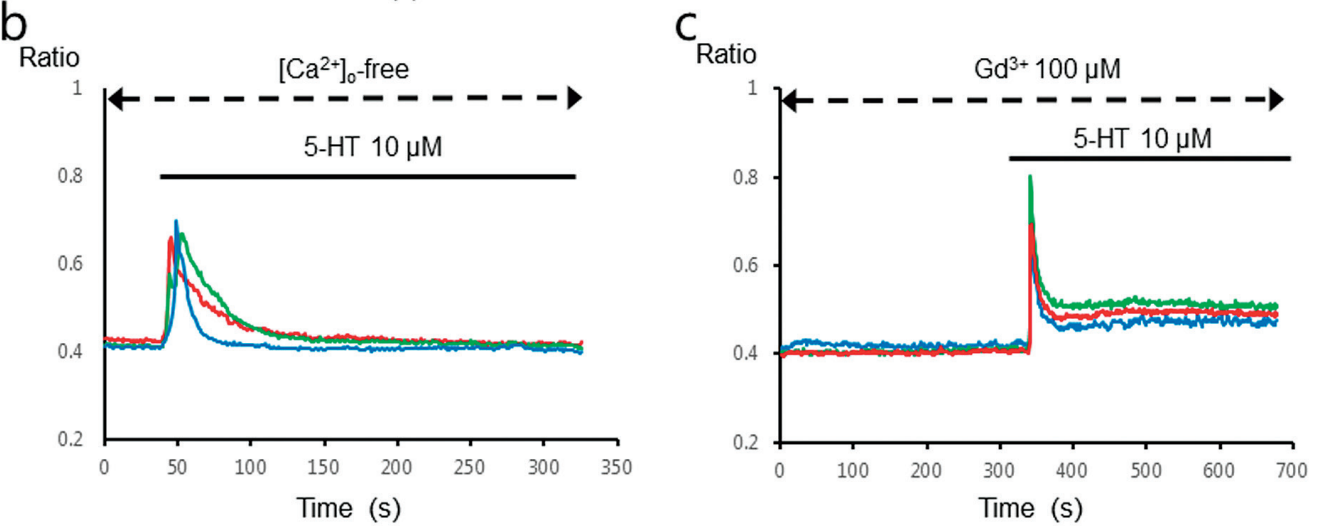

Fig. 3 Time courses of posterior ciliary arterial smooth muscle cells show the $\left[\mathrm{Ca}^{2+}\right]_{i}$ changes in areas of this size (about

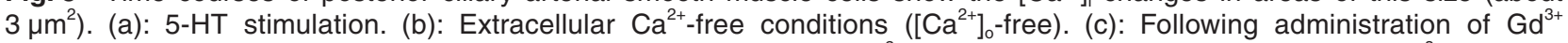
$(100 \mu \mathrm{M})$; a nonspecific cation channel blocker. However, neither $\left[\mathrm{Ca}^{2+}\right]_{0}$-free (b) nor treatment with $100 \mu \mathrm{M} \mathrm{Gd}^{3+}(\mathrm{c}) \mathrm{com}-$ pletely inhibited $5-\mathrm{HT}$-induced $\left[\mathrm{Ca}^{2+}\right]_{\mathrm{i}}$ increases. The pseudocolor images (a, right) illustrate a posterior ciliary artery showing the $\left[\mathrm{Ca}^{2+}\right]_{\mathrm{i}}$ changes observed over time following $5-\mathrm{HT}$ stimulation. Three regions of interest were set. 


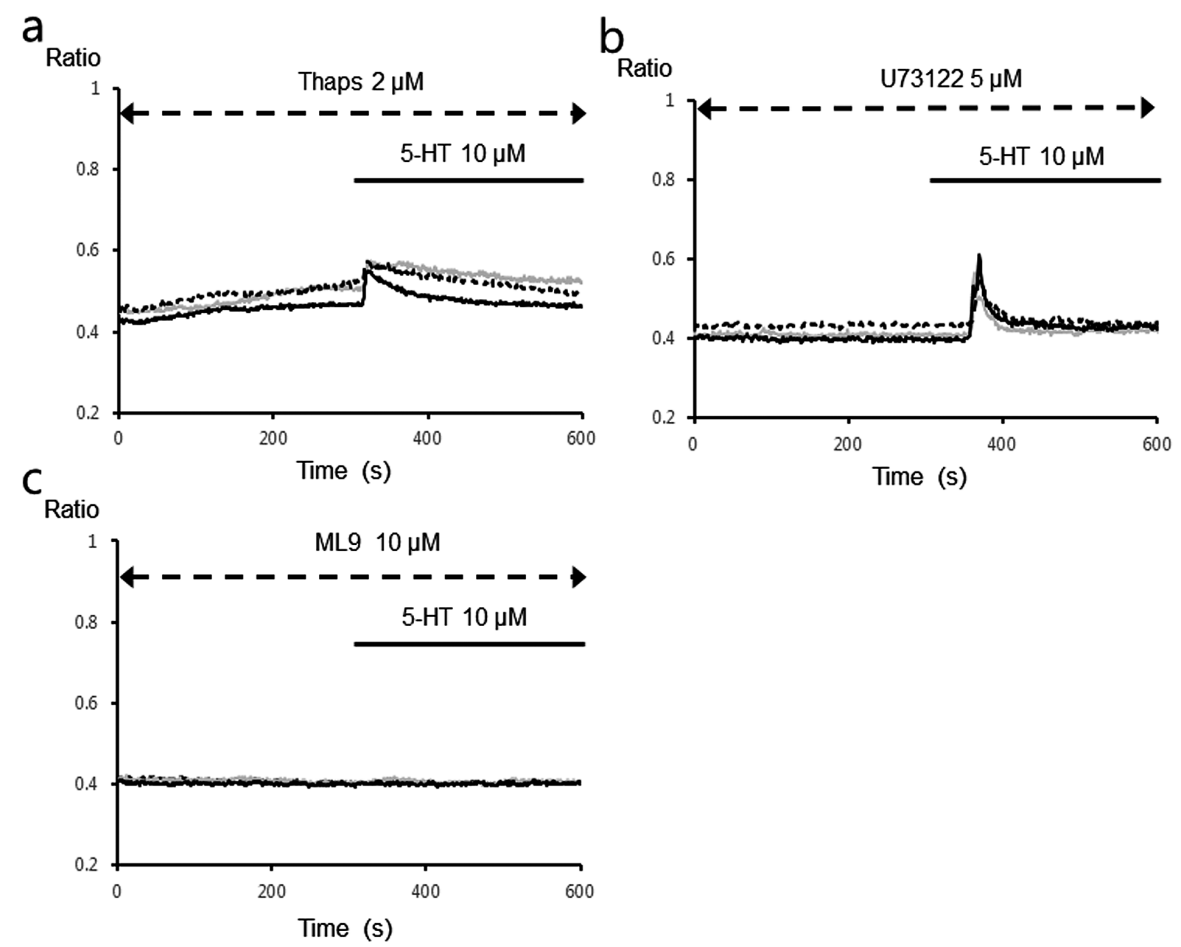

Fig. 4 Role for the mobilization of $\mathrm{Ca}^{2+}$ from intracellular $\mathrm{Ca}^{2+}$ stores during $5-\mathrm{HT}$-induced $\left[\mathrm{Ca}^{2+}\right]_{i}$ changes in areas of this size (about $\left.3 \mu \mathrm{m}^{2}\right)$. (a) 5-HT $(10 \mu \mathrm{M})$ induced only a slight $\left[\mathrm{Ca}^{2+}\right]_{i}$ increase in the cells after blockage of the sarco-endoplasmic reticulum $\mathrm{Ca}^{2+}$-ATPase by treatment with thapsigargin (Thaps, $2 \mu \mathrm{M}$ ). (b) Treatment with a phospholipase $\mathrm{C}$ antagonist, U73122 $(5 \mu \mathrm{M})$, partially inhibited the 5-HT-induced $\left[\mathrm{Ca}^{2+}\right]_{\mathrm{i}}$ increases. (c) Treatment with a myosin light chain kinase inhibitor, ML $9(10 \mu \mathrm{M})$, completely inhibited the 5 -HT-induced increases in $\left[\mathrm{Ca}^{2+}\right]_{\mathrm{i}}$. Three regions of interest were set.

U73122 were analyzed. The 5-HT-induced $\left[\mathrm{Ca}^{2+}\right]_{\mathrm{i}}$ increases in the cells were found to be partially prevented by pretreatment with thapsigargin $(n=8)$ (Fig. 4a). U73122 (5 $\mu \mathrm{M})$, an inhibitor of phospholipase $\mathrm{C}$, also partially inhibited the 5-HT-induced increases in $\left[\mathrm{Ca}^{2+}\right]_{\mathrm{i}}(n=9)$ (Fig. 4 b). Thus, both the $\mathrm{Ca}^{2+}$ influx from extracellular spaces and the $\mathrm{IP}_{3-}$ dependent $\mathrm{Ca}^{2+}$ mobilization from intracellular $\mathrm{Ca}^{2+}$ stores were induced by 5 -HT stimulation, suggesting that the mobilization of $\mathrm{Ca}^{2+}$ might be more significant than $\mathrm{Ca}^{2+}$ influx in the 5-HT-induced response. These results indicate that both $\mathrm{Ca}^{2+}$ influx and release result in a 5HT-induced $\left[\mathrm{Ca}^{2+}\right]_{\mathrm{i}}$ increase in posterior ciliary arteries.

Phosphorylation of myosin light chain (MLC) is one of the most important steps for vascular smooth muscle contraction $(37,66)$. To determine if this mechanism of the MLC kinase (MLCK) was involved in the 5-HT-induced $\left[\mathrm{Ca}^{2+}\right]_{\mathrm{i}}$ increase in our system, the effect of ML 9, an inhibitor of MLCK, was analyzed. We found that ML $9(10 \mu \mathrm{M})$ completely inhibited the 5-HT-induced increases in $\left[\mathrm{Ca}^{2+}\right]_{\mathrm{i}}(n=7)$ (Fig. 4c).
Effects of 5-HT and its analogs on $\left[\mathrm{Ca}^{2+}\right]_{i}$ dynamics in posterior ciliary arteries

We determined the effects of 5-HT and its analogs on posterior ciliary arteries to observe whether they are mediated via any of the recognized subtypes of 5 -HT receptors. In the presence of ketanserin, a $5-\mathrm{HT}_{2}$ antagonist, 5-HT induced little increase in the $\left[\mathrm{Ca}^{2+}\right]_{\mathrm{i}}$ in smooth muscle cells $(n=8)$ (Fig. 5a). In comparison, $\alpha$-methyl serotonin, a 5- $\mathrm{HT}_{2}$ agonist, induced a strong increase in the $\left[\mathrm{Ca}^{2+}\right]_{\mathrm{i}}$ in these cells $(n=8)$ (Fig. 5b). However, 2-methyl serotonin, a $5-\mathrm{HT}_{3}$ agonist, induced only a small increase in the $\left[\mathrm{Ca}^{2+}\right]_{\mathrm{i}}(n=8)$ (Fig. 5c). 8-Hydroxy-DPAT, a 5-HT agonist, also induced little increase in the $\left[\mathrm{Ca}^{2+}\right]_{\mathrm{i}}$ in smooth muscle cells $(n=8)$ (Fig. 6a), and CP93129, a $5-\mathrm{HT}_{1 \mathrm{~b}}$ agonist, induced a weak $\left[\mathrm{Ca}^{2+}\right]_{\mathrm{i}}$ increase compared with that from 5-HT $(n=8)$ (Fig. 6b). In contrast, H-89 $(20 \mu \mathrm{M})$, a PKA antagonist, did not inhibit the 5-HT-induced $\left[\mathrm{Ca}^{2+}\right]_{\mathrm{i}}$ response $(n=11)$ (Fig. 6c). The effect of $\mathrm{PKI}_{(14-22)}(2 \mu \mathrm{M})$, another PKA antagonist, was the same as that observed in the presence of H-89 $(n=8)$ (data not shown). SQ22536 $(100 \mu \mathrm{M})$ also did not completely block this increase $(n=8)$ (Fig. 6d). Together, these results 

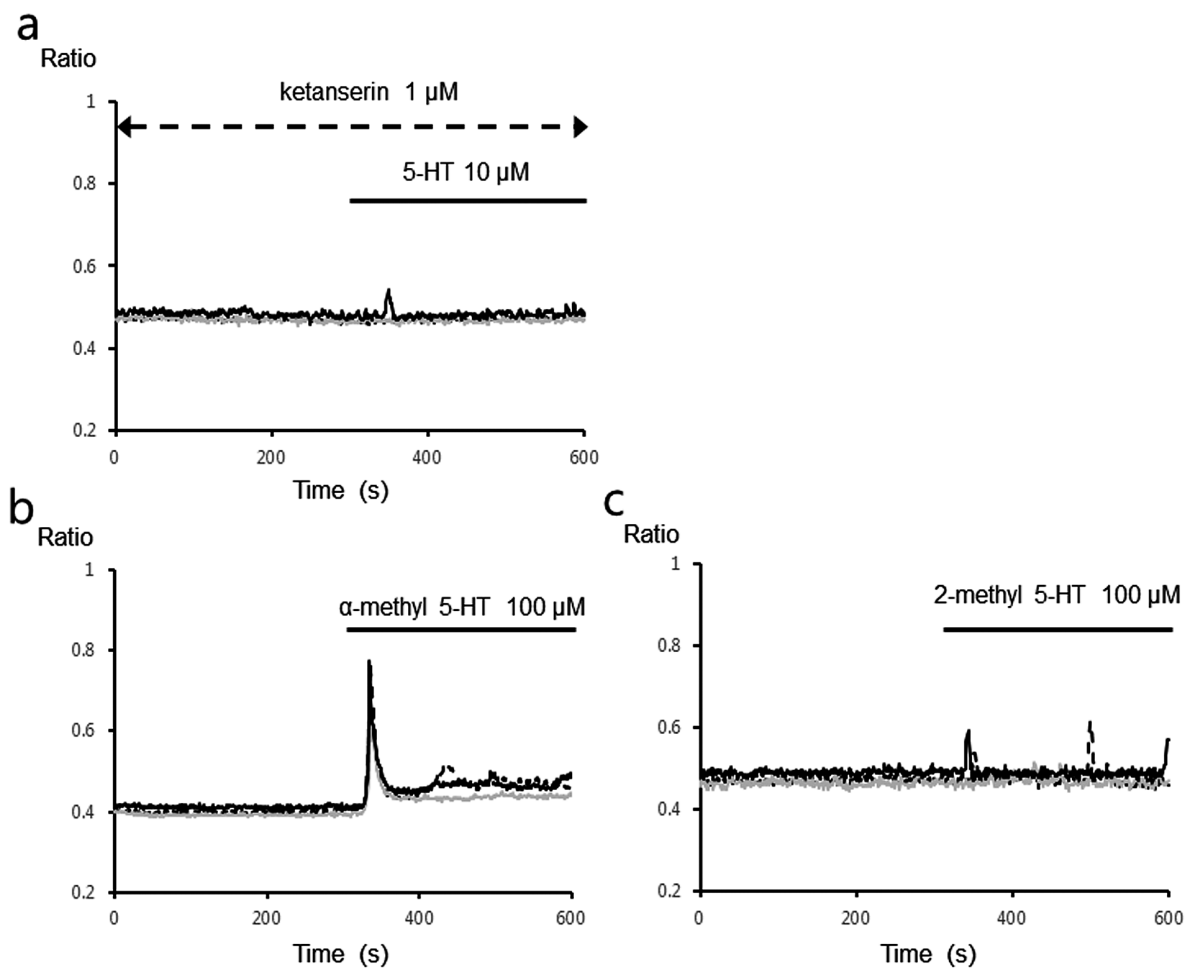

Fig. 5 Time courses for the $5-\mathrm{HT}$-induced $\left[\mathrm{Ca}^{2+}\right]_{i}$ dynamics effected using selected modifier drugs in posterior ciliary arterial smooth muscle cells in areas of this size (about $\left.3 \mu \mathrm{m}^{2}\right)$. (a): ketanserin $(1 \mu \mathrm{M}) ; \mathrm{a} 5-\mathrm{HT}_{2}$ antagonist; (b): $a$-methyl 5-HT $(100 \mu \mathrm{M})$; a 5- $\mathrm{HT}_{2}$ agonist; and (c): 2-methyl 5- $\mathrm{HT}(100 \mu \mathrm{M}) ;$ a $5-\mathrm{HT}_{3}$ agonist. Three regions of interest were set.

suggested that the cAMP dependent pathway $\left(5-\mathrm{HT}_{1}\right.$ and $\left.{ }_{4-7}\right)$ is insignificant in effecting vasocontraction following 5-HT stimulation in posterior ciliary arteries. Therefore, it can be concluded that the response of the posterior ciliary arteries is mediated by the $5-\mathrm{HT}_{1 \mathrm{~b}}, 5-\mathrm{HT}_{2}$, and $5-\mathrm{HT}_{3}$ receptors, and that 5- $\mathrm{HT}_{2}$ in particular plays a major role in these responses.

\section{5-HT-induced $\left[\mathrm{Ca}^{2+}\right]_{i}$ increase in vorticose veins}

Venous specimens were perfused with normal HR for $5 \mathrm{~min}$ before stimulation by the selected reagents. 5 -HT $(10 \mu \mathrm{M})$ induced an increase in the $\left[\mathrm{Ca}^{2+}\right]_{\mathrm{i}}$ in the smooth muscle cells of vorticose veins $(n=9)$ (Fig. 7a). The 5HT-induced $\left[\mathrm{Ca}^{2+}\right]_{\mathrm{i}}$ increases in vorticose veins were smaller than those in posterior ciliary arteries. In the absence of extracellular $\mathrm{Ca}^{2+}$, the increase in $\left[\mathrm{Ca}^{2+}\right]_{\mathrm{i}}$ was partially inhibited $(n=8)$ (Fig. 7b). The effect of $\mathrm{Gd}^{3+}$ in these cells was the same as that observed in the absence of $\mathrm{Ca}^{2+}$ (Fig. 7c). Diltiazem $(50 \mu \mathrm{M})$ also inhibited the ATP-induced $\left[\mathrm{Ca}^{2+}\right]_{\mathrm{i}}$ increases $(n=8)$ (data not shown). However, the 5-HT-induced $\left[\mathrm{Ca}^{2+}\right]_{\mathrm{i}}$ increases in the cells were completely prevented by pretreatment with thapsigargin $(n=9)$ (Fig. 8a), and the effect of U73122 $(5 \mu \mathrm{M})$ was the almost same $(n=7)$ (Fig. 8b). These results indicate that the increases in the $\left[\mathrm{Ca}^{2+}\right]_{\mathrm{i}}$ caused by 5 -HT result from $\mathrm{Ca}^{2+}$ released from the internal $\mathrm{Ca}^{2+}$ stores. Furthermore, to determine whether MLCK was involved in the 5-HT-induced $\left[\mathrm{Ca}^{2+}\right]_{i}$ increase in vorticose vein smooth muscle cells, the effect of ML 9 was analyzed and demonstrated that ML $9(10 \mu \mathrm{M})$ completely inhibited the 5-HT-induced increases in the $\left[\mathrm{Ca}^{2+}\right]_{\mathrm{i}}(n=7)($ Fig. 8c).

Effects of 5-HT and its analogs on the $\left[\mathrm{Ca}^{2+}\right]_{i} d y$ namics in vorticose veins

The effects of 5-HT and its analogs on vorticose veins were studied to observe whether they are mediated via any of the recognized subtypes of 5-HT receptors. In the presence of ketanserin, 5-HT induced little increase in the $\left[\mathrm{Ca}^{2+}\right]_{\mathrm{i}}$ in smooth muscle cells $(n=8)$ (Fig. 9a). $\alpha$-methylserotonin induced an increase in the $\left[\mathrm{Ca}^{2+}\right]_{\mathrm{i}}(n=8)$ (Fig. 9b), whereas 2-methylserotonin induced only a small increase in the $\left[\mathrm{Ca}^{2+}\right]_{\mathrm{i}}(n=8)$ (Fig. 9c). 8-Hydroxy-DPAT also induced little increase in $\left[\mathrm{Ca}^{2+}\right]_{\mathrm{i}}$ in these cells $(n=8)$ (Fig. 10a), whereas CP93129 induced no increase in the $\left[\mathrm{Ca}^{2+}\right]_{\mathrm{i}}(n=8)$ (Fig. 10b). In the presence of $\mathrm{H}-89(20 \mu \mathrm{M})$, the 5-HT-induced $\left[\mathrm{Ca}^{2+}\right]_{\mathrm{i}}$ increases in the cells were completely inhibited $(n=10)$ 

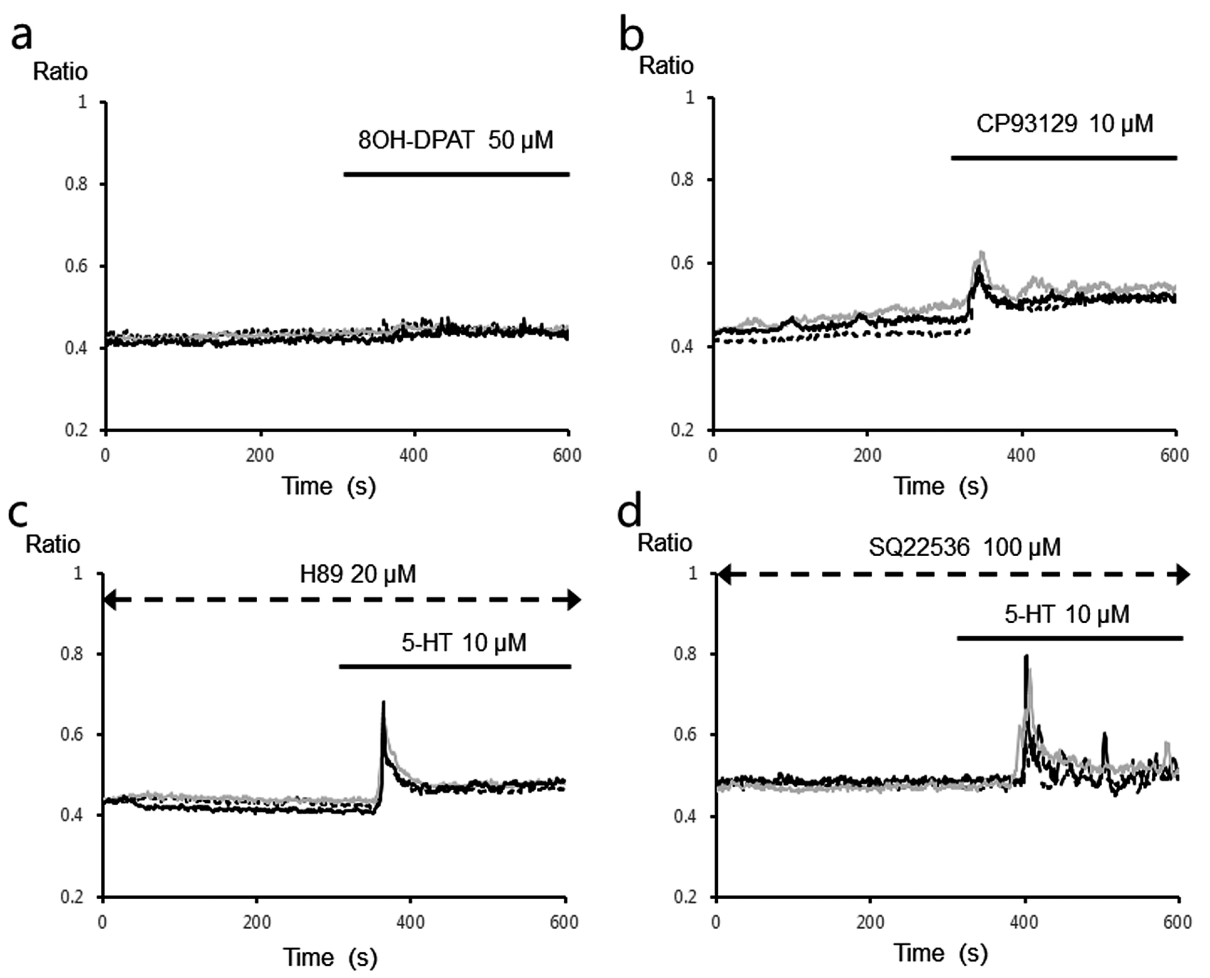

Fig. 6 Time courses for the $5-\mathrm{HT}$-induced $\left[\mathrm{Ca}^{2+}\right]_{\text {i }}$ dynamics effected using selected modifier drugs related to protein kinase A in posterior ciliary arterial smooth muscle cells in areas of this size (about $3 \mu^{2}{ }^{2}$ ). (a): $8-O H-D P A T ~(50 \mu M)$; a $5-H_{1}$ a ago-

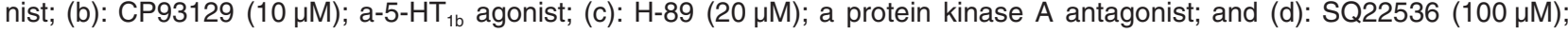
an adenylyl cyclase antagonist. Three regions of interest were set.

(Fig. 10c). The effect of $\mathrm{PKI}_{(14-22)}(2 \mu \mathrm{M})$ was the same as that observed in the presence of $\mathrm{H}-89(n=8)$ (data not shown). SQ22536 (100 $\mu \mathrm{M})$ also completely blocked this increase $(n=8)$ (Fig. 10d). Together, these results suggest that the 5-HT induced $\left[\mathrm{Ca}^{2+}\right]_{\mathrm{i}}$ mobilization within the vorticose veins can be mediated by $5-\mathrm{HT}_{2}$ and other cAMP-dependent pathways $\left(5-\mathrm{HT}_{4-7}\right)$, in contrast to the findings observed with posterior ciliary arteries.

\section{DISCUSSION}

Rat posterior ocular vasculature has a unique and simple angioarchitecture compared with that of the rabbit or primates. In these, the medial and lateral posterior ciliary arteries are present apart from the optic nerve $(68,69)$ whereas in rats, the posterior ciliary artery travels on the inferior side of the optic nerve sheath toward the optic disc. The posterior ciliary artery is derived from the inferior branch of the ophthalmic artery in the rat eye (26). The structure of rat posterior choroidal vasculature and posterior ciliary vein have previously been studied. However, most studies utilized the corrosion casting method $(48,49,70,84)$, which does not allow the examination of blood vessel function. Until now, few data have been available to allow the analysis of the signaling systems in intact ordinary vessels, in particular owing to the difficulty in extrapolating the signaling mechanisms identified in cultured cells to cells in vivo (75). Furthermore, few researchers have noted the significance of regional differences in smooth muscle cells (42). There are also few pharmaco-physiological studies on arterioles and venules, which play a pivotal role in tissue circulation, because of the difficulties in analyzing cellular reactions in intact arterioles and venules using conventional methods. It is likely, however, that venous smooth muscle cells can response to various transmitters and in particular 5-HT, in different ways than would arteriole smooth muscle cells. In addition, even though approximately $65 \%$ of the blood is contained in venous systems, there have been few studies related to the physiological response of venous smooth muscle cells to various transmitters/ modulators. The present study revealed that the response of arterial and venous smooth muscles to the vasoactive properties of 5-HT differed between pos- 

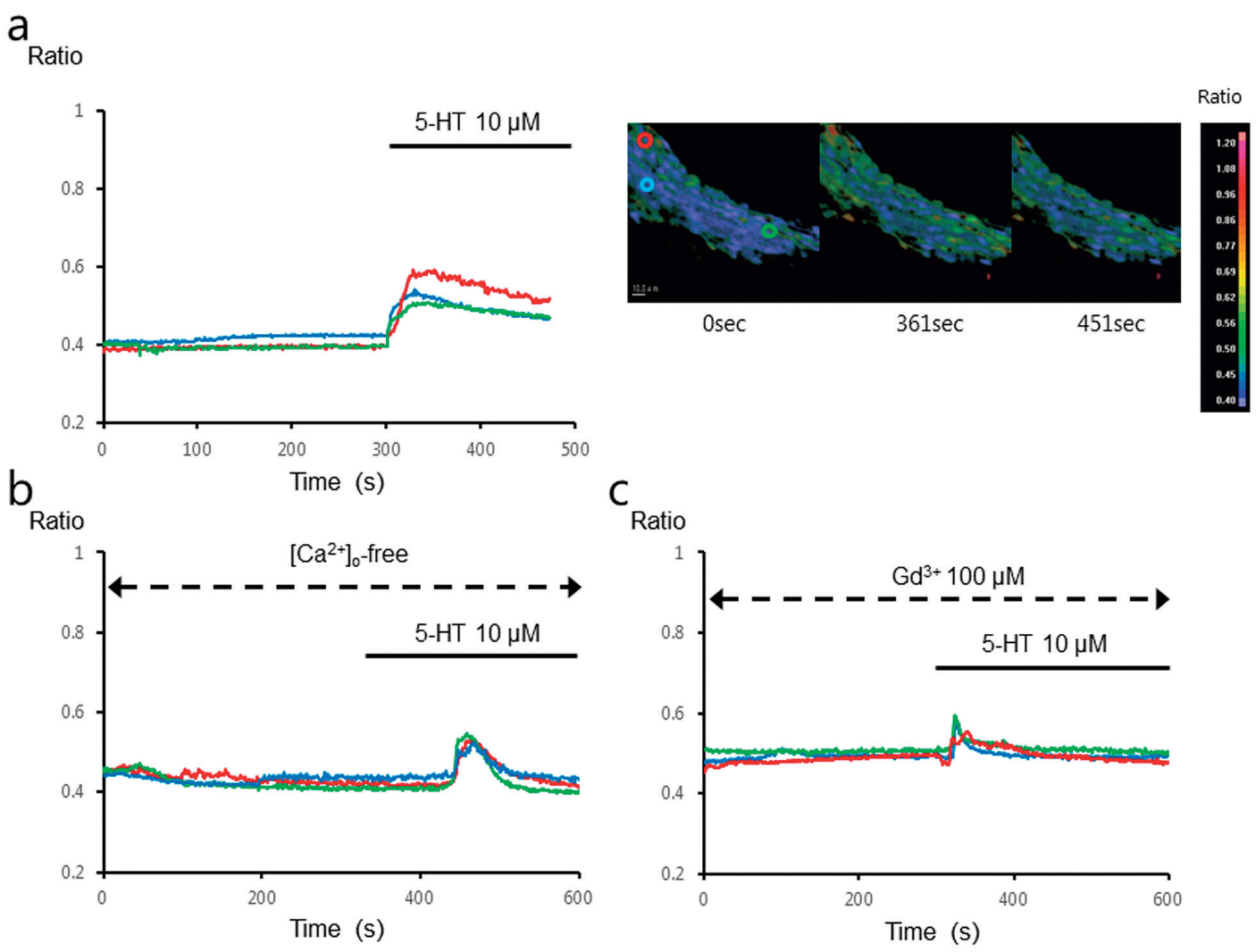

Fig. 7 Time courses of the vorticose venous smooth muscle cells showing the $\left[\mathrm{Ca}^{2+}\right]_{i}$ changes in areas of this size (about

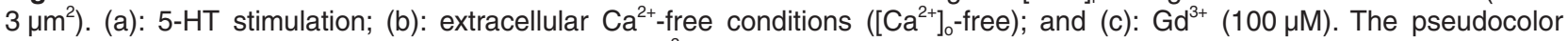
images $\left(\mathrm{a}\right.$, right) of the vorticose vein shows the $\left[\mathrm{Ca}^{2+}\right]_{i}$ changes following $5-\mathrm{HT}$ stimulation, indicating that ion channels are not entirely responsible for the $5-\mathrm{HT}$-induced $\left[\mathrm{Ca}^{2+}\right]_{i}$ changes. Three regions of interest were set.

terior ciliary arteries and veins. In the posterior ciliary arteries, the 5-HT-induced response of increased $\left[\mathrm{Ca}^{2+}\right]_{\mathrm{i}}$ was effected by both the $\mathrm{Ca}^{2+}$ influx from extracellular spaces and its release from internal stores, whereas the $\left[\mathrm{Ca}^{2+}\right]_{i}$ increase in the vorticose veins was much more dependent on the $\mathrm{Ca}^{2+}$ influx from extracellular spaces. Furthermore, the activation of smooth muscle contraction is thought to occur through increases in the $\left[\mathrm{Ca}^{2+}\right]_{i}$, activation of $\mathrm{Ca}^{2+} /$ calmodulin-dependent MLCK, and increases in MLC phosphorylation, as in the spastic canine basilar artery, where MLC has been shown to be phosphorylated by $\operatorname{MLCK}(22,38)$. Our results using a MLCK inhibitor in both arteries and veins were consistent with this model.

\section{Response to 5-HT in the posterior ciliary arteries}

Previous pharmaco-physiological studies reported that the $5-\mathrm{HT}_{1}$ and $5-\mathrm{HT}_{2}$ receptor families most commonly mediated the contractile responses to 5 -HT in certain vascular smooth muscles $(27,34$, $35,45,73,76)$, but the 5 -HT-induced $\left[\mathrm{Ca}^{2+}\right]_{\mathrm{i}}$ dynam- ics have not yet been studied. Using $\mathrm{Ca}^{2+}$ imaging, we previously demonstrated the details of the 5-HT receptors found in the cerebral arteries (external diameters $>50 \mu \mathrm{m})$; in these, $5-\mathrm{HT}_{1 \mathrm{a}}, 5-\mathrm{HT}_{1 \mathrm{~b}}, 5-\mathrm{HT}_{2}$, and $5-\mathrm{HT}_{3}$ receptors can be identified, with $5-\mathrm{HT}_{2}$ receptors playing a primary role (42). In this study, we found almost identical results for the ciliary arteries. Previously we were not able to detect any changes in the $\left[\mathrm{Ca}^{2+}\right]_{\mathrm{i}}$ dynamics of small arterioles $(<50 \mu \mathrm{m}$ in diameter) during 5-HT stimulation, indicating that smooth muscle cells in the peripheral cerebral blood vessels lack any response to 5-HT (42). In a hemorrhaged region, considerable amount of 5-HT is released from platelets, and if the smallsized arterioles of the brain express 5-HT receptors, the released 5-HT from a brain hemorrhage might induce severe vasoconstriction in the whole cerebral vascular network, resulting in fatal brain damage. A lack of response to 5-HT stimulation can lead to reactive hyperemia, in which the cerebral blood flow increases transiently following large artery occlusions $(33,43,87)$. In this context, previous physio- 
a

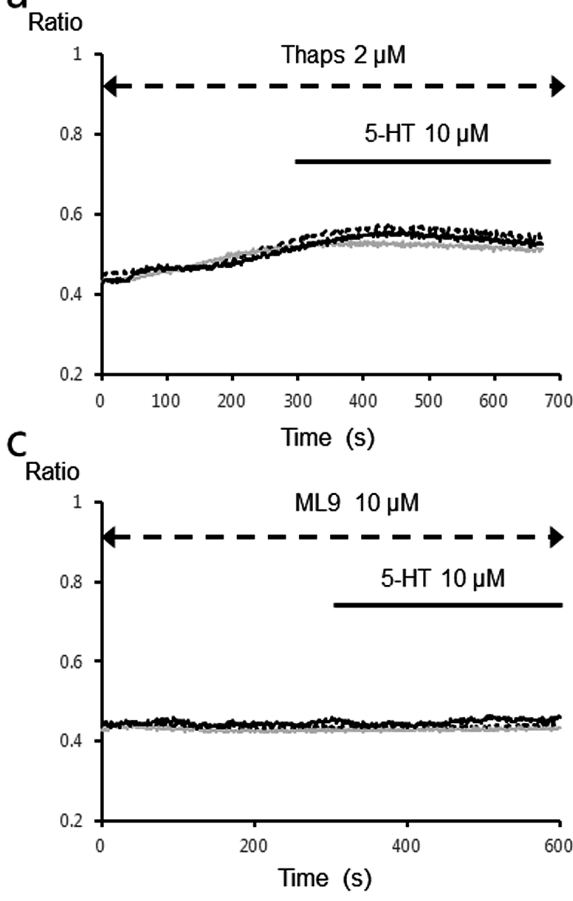

b

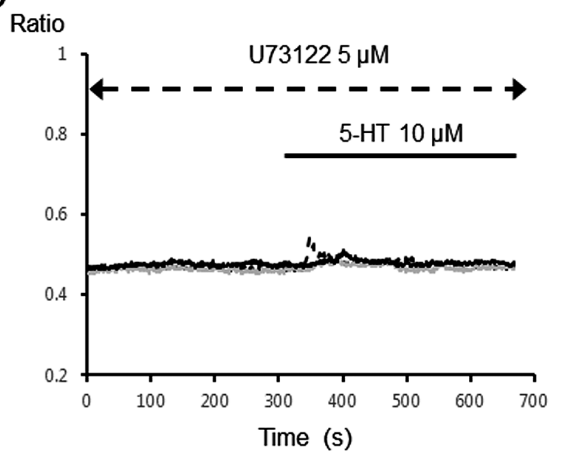

Fig. 8 Role for mobilization of $\mathrm{Ca}^{2+}$ from the intracellular $\mathrm{Ca}^{2+}$ stores in $5-\mathrm{HT}$-induced $\left[\mathrm{Ca}^{2+}\right]_{\mathrm{i}}$ changes in areas of this size (about $\left.3 \mu \mathrm{m}^{2}\right)$. (a): $5-\mathrm{HT}(10 \mu \mathrm{M})$ induced little $\left[\mathrm{Ca}^{2+}\right]_{\mathrm{i}}$ increase in the cells following treatment with thapsigargin $(2 \mu \mathrm{M})$. (b) U73122 $(5 \mu \mathrm{M})$ inhibited the 5-HT-induced $\left[\mathrm{Ca}^{2+}\right]_{\mathrm{i}}$ increases. (c) ML $9(10 \mu \mathrm{M})$ completely inhibited the 5-HT-induced increases in the $\left[\mathrm{Ca}^{2+}\right]_{\text {. }}$. Three regions of interest were set.

logical studies have reported that 5-HT constricted large arteries and reduced the vascular resistance of small vessels $(11,15,57,64,77,78)$. In vivo observation confirmed that 5 -HT induced the contraction of the pial vessel $(>200 \mu \mathrm{m}$ in resting diameter), whereas small vessels $(<70 \mu \mathrm{m}$ in diameter) were dilated (28). Notably, Teng et al. reported that the ratio of $5-\mathrm{HT}_{1}$ and $5-\mathrm{HT}_{2}$ receptors decreased progressively to their smallest values in second branch middle cerebral arteries or smaller segments (73).

In this study, the 5-HT-induced $\left[\mathrm{Ca}^{2+}\right]_{\mathrm{i}}$ dynamics observed in the posterior ciliary arteries appeared to be similar to the previously observed reactions in cerebral arteries. We previously reported the existence of regional differences and size-dependent manners of response to 5-HT in cerebral blood vessels, indicating that the regulatory mechanisms of blood circulation are highly differentiated in each region of the central nervous system. In ciliary arteries, the external diameters are almost same as those of the cerebral mid- and small-sized arterioles (external diameters $<50 \mu \mathrm{m}$ ) (42). By comparing our present data with that obtained previously, we suggest that the contraction of the cerebral arteries might be decided not only by the size of the relevant sections themselves but also by the number of divergences from main arteries (as the ophthalmic artery represents the first branch of the internal carotid artery).

\section{Response to 5-HT in the vorticose veins}

The marginal venous anastomosis of the peripapillary choroid plays a significant role in the venous drainage of the optic nerve head and the retinal vasculature. Previous reports indicate that the posterior ciliary veins as well as the vorticose veins provide venous drainage of the posterior choroid in the rat $(70,84)$. The microvascular supply and drainage of the optic nerve and the peripapillary choroid have been studied in the rabbit (68), nonhuman primates (69), and humans (50) using physiologically controlled microvascular corrosion castings $(1,5,16$, $47,70,82$ ), which permanently replicate the anatomic condition of the vascular beds under the physiologic conditions at the time of plastic injection. Such a plastic model of the ocular vasculature appears to preserve the vascular tone. However, most studies have of necessity observed only the diversity of the arteries and veins and not their physiological response.

Most physiological studies of the venous system 

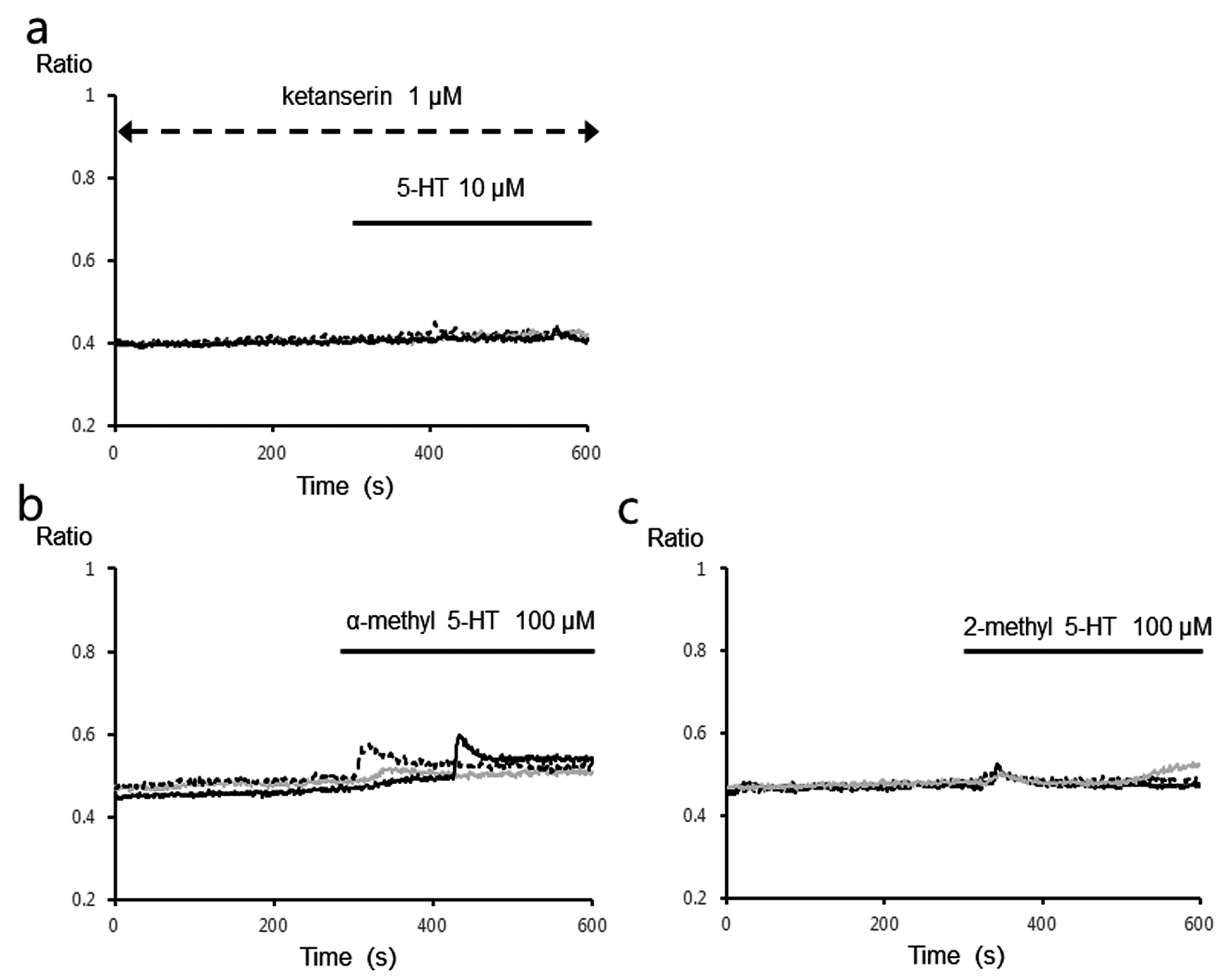

Fig. 9 Time courses for the 5-HT-induced $\left[\mathrm{Ca}^{2+}\right]_{i}$ dynamics effected using selected modified drugs in vorticose venous smooth muscle cells in areas of this size (about $\left.3 \mu \mathrm{m}^{2}\right)$. (a): ketanserin (1 $\left.\mu \mathrm{M}\right)$, (b): $a$-methyl 5-HT (100 $\left.\mu \mathrm{M}\right)$, (c): $2-\mathrm{methyl}$ 5 -HT $(100 \mu \mathrm{M})$. Three regions of interest were set.

have utilized the portal veins, and few have examined the function of the venous smooth muscle cells. Takahashi et al., using real-time confocal laser scanning microscopy, revealed that a transient and periodic increase in the $\left[\mathrm{Ca}^{2+}\right]_{i}$ occurred within the longitudinal smooth muscle cells and was transmitted spirally from the intestinal to the hepatic side of the hepatic portal veins (71). The current study represents the first to incorporate the use of a calcium imaging technique to compare the ophthalmic arteries and veins. For the portal veins, the longitudinal smooth muscle cells were shown to span the interval of the fold in the manner of a spirally arranged palisade around the vessel wall (71). In the present study, the veins were surrounded by smooth muscle cells in the shape of cobblestones. Previous scanning electron microscopy studies have shown that muscular venules consist of at least one layer of flat cells similar to the flattened smooth muscle cells characteristically observed in the walls of the veins of the rat mammary gland (24) and of the venous segments of rabbit ear arteriovenous anastomoses (23). Our confocal laser scanning microscopy provided similar images of smooth muscle cells in the analyzed vessels. In the future, it will be necessary to verify whether the streaming of the vorticose venous smooth muscle cell alignment differs from that of other veins. Here, we demonstrated that the 5-HT-induced $\left[\mathrm{Ca}^{2+}\right]_{i}$ dynamics in the vorticose veins differed from that of the posterior ciliary arteries.

Our results suggested that the receptors responsible for 5-HT response in the posterior ciliary arteries and veins are most likely $5-\mathrm{HT}_{2-7}$, whereas the cerebral vasculature can possess $5-\mathrm{HT}_{1 \mathrm{a}}, 5-\mathrm{HT}_{1 \mathrm{~b}}, 5-\mathrm{HT}_{2}$, and $5-\mathrm{HT}_{3}$ receptors. Also, it is possible that PKA interacts with upstream of the $\mathrm{IP}_{3}$ receptors in the vorticose veins. Compared to the ciliary arteries, the PKA-dependent 5-HT receptors (i.e., 5- $\mathrm{HT}_{4-7}$ ) are more dominant than the $5-\mathrm{HT}_{2}$ receptors in the vorticose veins. It seems probable that veins do not require a delicate control mechanism to regulate tissue circulation. A previous study, which examined the intracellular structure of the endothelium lining of vein-to-artery grafts, demonstrated that the surface area of the rough endoplasmic reticulum was significantly increased up to 26 weeks after graft insertion, but not at 52 weeks (74). Between arterioles and venules, the latter exhibit endothelial cells containing few organelles such as mitochondria, dense bodies, and granular endoplasmic reticulum (14). 

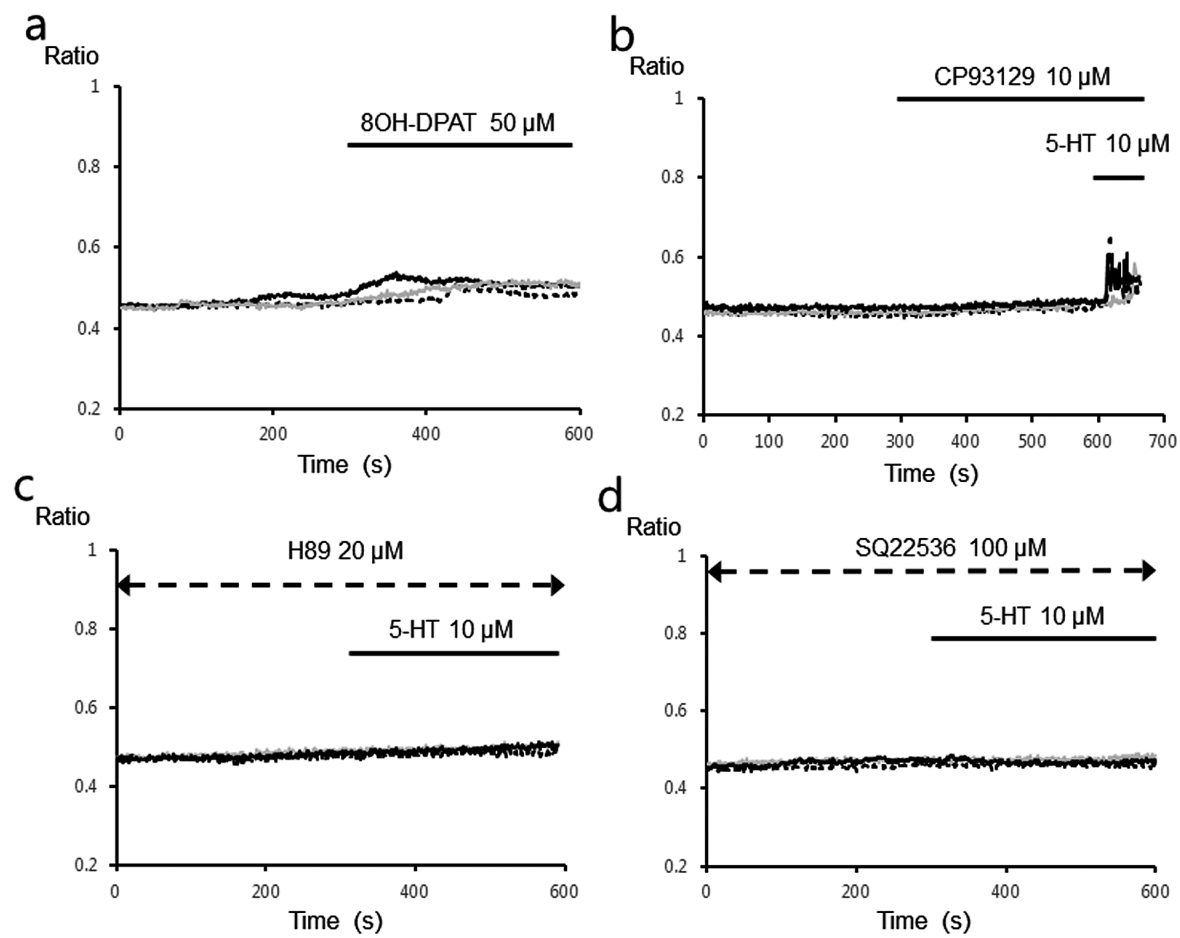

Fig. 10 Time courses for the 5-HT-induced $\left[\mathrm{Ca}^{2+}\right]_{\mathrm{i}}$ dynamics effected using selected modified drugs related to protein kinase $A$ in vorticose venous smooth muscle cells in areas of this size are shown (about $\left.3 \mu m^{2}\right)$. (a): $8-O H-D P A T(50 \mu M) ;(b)$ :

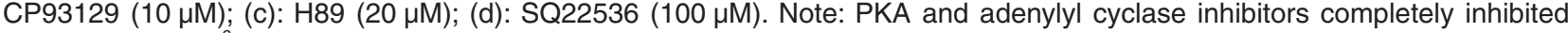
$5-\mathrm{HT}$-induced $\left[\mathrm{Ca}^{2+}\right]_{\mathrm{i}}$ increases in vorticose venous smooth muscle cells. Three regions of interest were set.

We therefore suggest that the $\mathrm{Ca}^{2+}$ influx is much more dominant than the $\mathrm{Ca}^{2+}$ mobilization related to $\mathrm{Ca}^{2+}$ release from the endoplasmic reticulum in veins compared to arteries.

\section{Conclusion}

Our examination of the response to 5-HT in posterior ciliary arteries and vorticose veins demonstrated that arterial and venous smooth muscle cells might serve in a great variety of responsibilities which could not have found out in previous studies. 5-HT receptors in posterior ciliary arteries and vorticose veins play important roles in the regulation of vascular functions. In the present study, the receptors that function in arterial and venous smooth muscle cells were shown to differ within the same tissue, suggesting that the consequences of 5-HT-induced $\left[\mathrm{Ca}^{2+}\right]_{\mathrm{i}}$ increase in vivo are not the same between these cells. These results indicate that the tissue/organ-specific characteristics of vascular function must be taken into consideration when determining their physiological responses. Therefore, clarification of their specificities is essential for the development of therapies designed to improve the blood circulation in given tissues/organs.

\section{Acknowledgements}

This work was supported by research grants from the Ministry of Education, Culture, Sports, Science, and Technology of Japan (Y.S., 15K08157; T.S., 24590259) and from Grants-in-Aid for Strategic Medical Science Research (S1491001, 2014-2018). Some of this work was performed at the Advanced Medical Science Center of Iwate Medical University, which also provided financial support.

The authors declare no competing financial interests.

\section{REFERENCES}

1. Ahmed Bhutto I and Amemiya T (2001) Corrosion casts and scanning electron microscopy of choroidal vasculature in rats with inherited hypercholesterolemia. Curr Eye Res 23, 240247.

2. Baumgarten HG and Grozdanovic Z (1997) Anatomy of the central serotoninergic projection systems. In: Serotoninergic Neurons and 5-HT Receptors in the CNS (Baumgarten HG, Gothert M, eds), pp41-89, Springer-Verlag, Berlin.

3. Berridge MJ (2009) Inositol trisphosphate and calcium signalling mechanisms. Biochim Biophys Acta 1793, 933-940.

4. Bhutto IA and Amemiya T (1995) Retinal vascular changes during aging in Wistar Kyoto rats. Application of corrosion 
cast and scanning electron microscopy. Ophthalmic Res 27, 249-261.

5. Bhutto IA and Amemiya T (2001) Retinal vascular architecture is maintained in retinal degeneration: corrosion cast and electron microscope study. Eye (Lond) 15, 531-538.

6. Bill A (1984) Circulation in the eye. In: Handbook of Physiology. Microcirculation, Part 2 (Renkin EM, Michel CC, eds), pp1001-1035, The American Physiological Society, Bethesda.

7. Boehm AG, Koeller AU and Pillunat LE (2005) The effect of age on optic nerve head blood flow. Invest Ophthalmol Vis Sci 46, 1291-1295.

8. Bradley PB, Engel G, Feniuk W, Fozard JR, Humphrey PP, Middlemiss DN, Mylecharane EJ, Richardson BP and Saxena PR (1986) Proposals for the classification and nomenclature of functional receptors for 5-hydroxytryptamine. Neuropharmacology 25, 563-576.

9. Chatziralli IP, Jaulim A, Peponis VG, Mitropoulos PG and Moschos MM (2014) Branch retinal vein occlusion: Treatment modalities: An update of the literature. Semin Ophthalmol 29, 85-107.

10. Cheung CY, Ikram MK, Sabanayagam C and Wong TY (2012) Retinal microvasculature as a model to study the manifestations of hypertension. Hypertension 60, 1094-1103.

11. Cohen RA, Shepherd JT and Vanhoutte PM (1983) 5-Hydroxytryptamine can mediate endothelium-dependent relaxation of coronary arteries. Am J Physiol 245, H1077-H1080.

12. Crowell MD, Shetzline MA, Moses PL, Mawe GM and Talley NJ (2004) Enterochromaffin cells and 5-HT signaling in the pathophysiology of disorders of gastrointestinal function. Curr Opin Investig Drugs 5, 55-60.

13. Dimitrova G, Tamaki Y and Kato S (2002) Retrobulbar circulation in patients with age-related maculopathy. Eye 16, 580-586.

14. Ebe T and Kobayashi S (1972) Fine Structure of Human Cells and Tissues, pp28-35, Wiley, New York.

15. Faraci FM and Heistad DD (1990) Regulation of large cerebral arteries and cerebral microvascular pressure. Circ Res 66, 8-17.

16. Fahrenbach WH, Bacon DR, Morrison JC and Van Buskirk EM (1988) Controlled vascular corrosion casting of the rabbit eye. J Electron Microsc Tech 10, 15-26.

17. Flammer J, Konieczka K, Bruno RM, Virdis A, Flammer AJ and Taddei S (2013) The eye and the heart. Eur Heart J 34, $1270-1278$.

18. Fozard JR (1987) The pharmacological basis of migrane treatment. In: Migrane : Clinical \& Research Aspects (Blau J, ed), pp165-184, The Johns Hopkins University Press, Baltimore.

19. Fozard JR (1989) 5-HT in migrane: evidence from 5-HT receptor antagonists for a neuronal aetiology. In: Migrane: A Spectrum of Ideas (Sandler M, Collins G, eds), pp128-141, Oxford University Press, Oxford.

20. Fryczkowski AW, Grimson BS and Peiffer RL (1985) Vascular casting and scanning electron microscopy of human ocular vascular abnormalities. Arch Ophthalmol 103, 118-120.

21. Funk R (1986) Studies on the functional morphology of rat ocular vessels with scanning electron microscopy. Acta Anat 125, 252-257.

22. Fujikawa H, Tani E, Yamaura I, Ozaki I, Miyaji K, Sato M, Takahashi K and Imajoh-Ohmi S (1999) Activation of protein kinases in canine basilar artery in vasospasm. $J$ Cereb Blood Flow Metab 19, 44-52.

23. Fujiwara $\mathrm{T}$ and Iijima $\mathrm{T}$ (1990) Three-dimensional cytoarchitecture of the media of arteriovenous anastomoses in the rab- bit ear. Am J Anat 189, 253-260.

24. Fujiwara T and Uehara Y (1984) The cytoarchitecture of the wall and the innervation pattern of the microvessels in the rat mammary gland: a scanning electron microscopic observation. Am J Anat 170, 39-54.

25. Gerhardt CC and van Heerikhuizen H (1997) Functional characteristics of heterologously expressed 5-HT receptors. Eur J Pharmacol 334, 1-23.

26. Greene EC (1963) Anatomy of the Rat. Hafner Publishing, New York.

27. Hamel E, Robert JP, Young AR and MacKenzie ET (1989) Pharmacological properties of the receptor(s) involved in the 5-hydroxytryptamine-induced contraction of the feline middle cerebral artery. J Pharmacol Exp Ther 249, 879-889.

28. Harper AM and MacKenzie ET (1977) Effects of 5-hydroxytryptamine on pial arteriolar calibre in anaesthetized cats. $J$ Physiol, 271, 735-746.

29. Hayreh SS (2001) The blood supply of the optic nerve head and the evaluation of it - myth and reality. Prog Retin Eye Res 20, 563-593.

30. Hayreh SS, Zimmerman MB, Kimura A and Sanon A (2004) Central retinal artery occlusion. Exp Eye Res 78, 723-736.

31. Hayreh SS and Zimmerman MB (2005) Central retinal artery occlusion: visual outcome. Am J Ophthalmol 140, 376-391.

32. Hogan MJ and Feeney L (1963) The ultrastructure of the retinal blood vessels. I. The large vessels. J Ultrastruct Res 39, $10-28$.

33. Hossmann KA (1997) Reperfusion of the brain after global ischemia: hemodynamic disturbances. Shock 8, 95-101.

34. Hoyer D, Clarke DE, Fozard JR, Hartig PR, Martin GR, Mylecharane EJ, Saxena PR and Humphrey PP (1994) International Union of Pharmacology classification of receptors for 5-hydroxytryptamine (Serotonin). Pharmacol Rev 46, $157-203$.

35. Hoyer D, Hannon JP and Martin GR (2002) Molecular, pharmacological and functional diversity of 5-HT receptors. Pharmacol Biochem Behav 71, 533-554.

36. Jo-Osvatic A, Basic N, Jukic T, Nikolic V and Stimac D (1999) Topoanatomic relations of the ophthalmic artery viewed in four layers. Surg Radiol Anat 21, 371-375.

37. Kamm KE and Stull JT (1989) Regulation of smooth muscle contractile elements by second messengers. Annu Rev Physiol 51, 299-313.

38. Kokubu K, Tani E, Nakano M, Minami N and Shindo H (1989) Effects of ML-9 on experimental delayed cerebral vasospasm. J Neurosurg 71, 916-922.

39. Koss MC and Gherezghiher T (1993) Adrenoceptor subtypes involved in neurally evoked sympathetic vasoconstriction in the anterior choroid of cats. Exp Eye Res 57, 441-447.

40. Leung H, Wang JJ, Rochtchina E, Tan AG, Wong TY, Klein R, Hubbard LD and Mitchell P (2003) Relationships between age, blood pressure, and retinal vessel diameters in an older population. Invest Ophthalmol Vis Sci 44, 2900-2904.

41. MacKenzie ET and Scatton B (1987) Cerebral circulatory and metabolic effects of perivascular neurotransmitters. CRC Crit Rev Clin Neurobiol 2, 357-419.

42. Masu K, Saino T, Kuroda T, Matsuura M, Russa AD, Ishikita N and Satoh Y (2008) Regional differences in 5-HT receptors in cerebral and testicular arterioles of the rat as revealed by $\mathrm{Ca}^{2+}$ imaging of real-time confocal microscopy: variances by artery size and organ specificity. Arch Histol Cytol 71, 291-302.

43. Matsubara J, Narumi J, Nagasue M, Sakamoto S, Yuasa K and Shimizu T (1998) Postocclusive reactive hyperemia dur- 
ing vascular reconstruction. Internatl J Angiol 7, 222-227.

44. Matsuura M, Saino T and Satoh Y (2004) Response to ATP is accompanied by a $\mathrm{Ca}^{2+}$ influx via $\mathrm{P} 2 \mathrm{X}$ purinoceptors in the coronary arterioles of golden hamsters. Arch Histol Cytol 67, 95-105.

45. Miranda FJ, Torregrosa G, Salom JB, Alabadi JA, Jover T, Barbera MD and Alborch E (1995) Characterization of 5-hydroxytryptamine receptors in goat cerebral arteries. Gen Pharmacol 26, 1267-1272.

46. Misaki T, Satoh Y, Saino T and Ogawa A (2006) The role of protease-activated receptors on the intracellular calcium ion dynamics of vascular smooth muscles, with special reference to cerebral arterioles. Arch Histol Cytol 69, 49-60.

47. Morrison JC, Fraunfelder FW, Milne ST and Moore CG (1995) Limbal microvasculature of the rat eye. Invest Ophthalmol Vis Sci 36, 751-756.

48. Ninomiya H (2002) Vasculature of the ophthalmic rete in night herons (Nycticorax nycticorax): scanning electron microscopy of corrosion casts. Vet Ophthalmol 5, 155-160.

49. Ninomiya $H$ and Inomata $T$ (2005) Microvasculature of the hamster eye: scanning electron microscopy of vascular corrosion casts. Vet Ophthalmol 8, 7-12.

50. Onda E, Cioffi GA, Bacon DR and Van Buskirk EM (1995) Microvasculature of the human optic nerve. Am J Ophthalmol 120, 92-102.

51. Pannarale L, Onori P, Ripani M and Gaudio E (1991) Retinal microcirculation as revealed by SEM corrosion casts in the rat. Eur J Ophthalmol 1, 96-102.

52. Park SJ, Choi NK, Seo KH, Park KH and Woo SJ (2014) Nationwide incidence of clinically diagnosed central retinal artery occlusion in Korea, 2008 to 2011. Ophthalmology 121, 1933-1938.

53. Patton N, Aslam T, MacGillivray T, Pattie A, Deary IJ and Dhillon B (2005) Retinal vascular image analysis as a potential screening tool for cerebrovascular disease: a rationale based on homology between cerebral and retinal microvasculatures. J Anat 206, 319-348.

54. Petrella RJ, Blouin J, Davies B and Barbeau M (2012) Incidence and characteristics of patients with visual impairment due to macular edema secondary to retinal vein occlusion in a representative Canadian cohort. $J$ Ophthalmol 2012, 723169.

55. Racke K, Reimann A, Schworer H and Kilbinger H (1996) Regulation of 5-HT release from enterochromaffin cells. Behav Brain Res 73, 83-87.

56. Ramage AG and Villalón CM (2008) 5-Hydroxytryptamine and cardiovascular regulation. Trends Pharmacol Sci 29, 472-481.

57. Rapport MM (1949) Serum vasoconstrictor (serotonin). V: The presence of creatinine in the complex. A proposed structure of the vasoconstrictor principle. J Biol Chem 186, 615623.

58. Roth BL, Willins DL, Kristiansen K and Kroeze WK (1998) 5-Hydroxytryptamine2-family receptors (5-hydroxytryptamine2A, 5-hydroxytryptamine2B, 5-hydroxytryptamine2C): where structure meets function. Pharmacol Ther 79, 231257.

59. Ruskell GL (1970) The orbital branches of the pterygopalatine ganglion and their relationship with internal carotid nerve branches in primates. $J$ Anat 106, 323-339.

60. Saida A, Ito H, Shibuya T and Watanabe Y (1997) Timecourse alterations of monoamine levels and cerebral blood flow in brain regions after subarachnoid hemorrhage in rats. Brain Res Bull 43, 69-80.
61. Saino T, Matsuura M and Satoh Y (2002) Application of real-time confocal microscopy to intracellular calcium ion dynamics in rat arterioles. Histochem Cell Biol 117, 295-305.

62. Saino T, Matsuura M and Satoh Y (2002) Comparison of the effect of ATP on intracellular calcium ion dynamics between rat testicular and cerebral arteriole smooth muscle cells. Cell Calcium 32, 155-165.

63. Saino T and Satoh Y (2004) Application of real-time confocal laser scanning microscopy to observe living cells in tissue specimens. J Electron Microsc (Tokyo) 53, 49-56.

64. Sjaastad O (1975) The significance of blood serotonin levels in migraine. A critical review. Acta Neurol Scand 51, 200-210.

65. Soares AS, Artes PH, McCormick TA, LeBlanc RP, Nicolela MT and Chauhan BC (2003) Retinal arterial diameter changes in progressive and non-progressive glaucoma. J Glaucoma 12, 243-249.

66. Somlyo AP and Somlyo AV (1994) Signal transduction and regulation in smooth muscle. Nature 372, 231-236.

67. Steinle JJ, Krizsan-Agbas D and Smith PG (2000) Regional regulation of choroidal blood flow by autonomic innervation in the rat. Am J Physiol Regul Integr Comp Physiol 279, R202-R209.

68. Sugiyama K, Bacon DR, Morrison JC and Van Buskirk EM (1992) Optic nerve head microvasculature of the rabbit eye. Invest Ophthalmol Vis Sci 33, 2251-2261.

69. Sugiyama K, Cioffi GA, Bacon DR and Van Buskirk EM (1994) Optic nerve and peripapillary choroidal microvasculature in the primate. J Glaucoma 3 Suppl, S45-S54.

70. Sugiyama K, Gu ZB, Kawase C, Yamamoto T and Kitazawa Y (1999) Optic nerve and peripapillary choroidal microvasculature of the rat eye. Invest Ophthalmol Vis Sci 40, 30843090.

71. Takahashi S, Hitomi J, Satoh Y, Takahashi T, Asakura H and Ushiki T (2002) Fine structure of the mouse portal vein in relation to its peristaltic movement. Arch Histol Cytol 65, 71-82.

72. Tan AG, Wang JJ, Rochtchina E, Klein R, Wong TY, Hubbard LD and Mitchell P (2003) Correlation between generalized and focal retinal arteriolar narrowing in an older population. Clin Exp Ophthalmol 31, 322-325.

73. Teng GQ, Williams J, Zhang L, Purdy R and Pearce WJ (1998) Effects of maturation, artery size, and chronic hypoxia on 5-HT receptor type in ovine cranial arteries. Am J Physiol 275, R742-R753.

74. Tennant M and McGeachie J (1996) Long-term structural alterations to endothelial cells in vein-to-artery grafts: a quantitative electron microscopic study. Anat Embryol (Berl) 193, 169-173.

75. Ueki N, Sobue K, Kanda K, Hada T and Higashino K (1987) Expression of high and low molecular weight caldesmons during phenotypic modulation of smooth muscle cells. Proc Nat Acad Sci USA 84, 9049-9053.

76. Ullmer C, Schmuck K, Kalkman HO and Lübbert H (1995) Expression of serotonin receptor mRNAs in blood vessels. FEBS Lett 370, 215-221.

77. Van Nueten JM (1985) Serotonin and the blood vessel wall. $J$ Cardiovasc Pharmacol 7 Suppl, S49-S51.

78. Van Nueten JM, Janssens WJ and Vanhoutte PM (1985) Serotonin and vascular reactivity. Pharmacol Res Commun 17, 585-608.

79. Van Overbeeke J and Sekhar L (2003) Microanatomy of the blood supply to the optic nerve. Orbit 22, 81-88.

80. Vanhoutte PM, Cohen RA and Van Nueten JM (1984) Serotonin and arterial vessels. J Cardiovasc Pharmacol 6 Suppl, 
S421-S428.

81. Wang JJ, Rochtchina E, Liew G, Tan AG, Wong TY, Leeder SR, Smith W, Shankar A and Mitchell P (2008) The longterm relation among retinal arteriolar narrowing, blood pressure, and incident severe hypertension. Am J Epidemiol 168, 80-88.

82. Yamakawa K, Bhutto IA, Lu Z, Watanabe Y and Amemiya T (2001) Retinal vascular changes in rats with inherited hypercholesterolemia - corrosion cast demonstration. Curr Eye Res 22, 258-265.

83. Yamamoto S, Takatsuna Y, Sato E and Mizunoya S (2005) Central retinal artery occlusion after radial optic neurotomy in a patient with central retinal vein occlusion. Am J Ophthalmol 139, 206-207.

84. Yoshimoto H, Murata M, Yamagami K and Matsuyama S (1980) Studies on the angioarchitecture of the posterior cho- roid in rat and role of posterior ciliary vein. Invest Ophthalmol Vis Sci 19, 1245-1250.

85. Young AR, Hamel E and MacKenzie ET (1986) Recent studies on the serotonergic innervation of the cerebral circulation: a review. In: Neural Regulation of Brain Circulation, Vol.8 (Owman C, Hardebo JE, eds), pp195-217, Elsevier, New York.

86. Young AR, Hamel E, MacKenzie ET, Seylaz J and Verrecchia C (1987) The multiple actions of 5-hydroxytryptamine on cerebrovascular smooth muscle. In: Neural Messengers in Vascular Function, Vol.10 (Nobin A, Owman C, ArnelloNobin B, eds), pp57-74, Elsevier, New York.

87. Zimmer R, Lang R and Oberdörster G (1971) Post-ischemic reactive hyperemia of the isolated perfused brain of the dog. Pflüg Arch 328, 332-343. 